\title{
Explicating the Experience of Beginner Vocational Teachers
}

\author{
Nur Kholifah ${ }^{1}$, Herminarto Sofyan ${ }^{1}$, Pardjono Pardjono ${ }^{1}$, \\ Putu Sudira ${ }^{1}$, Muhammad Nurtanto ${ }^{2}$ \\ ${ }^{1}$ Graduate School, Yogyakarta State University Jl. Colombo No.1, Yogyakarta, 55281 Indonesia \\ ${ }^{2}$ Department of Mechanical Engineering Education, Universitas Sultan Ageng Tirtayasa, Jl. Raya Jakarta \\ Km 4, Banten, 42118 Indonesia
}

\begin{abstract}
The limitations of teachers in vocational schools have been discussed and debated. This situation is contrary to professional teachers and teacher quality. Thus, vocational school administrators have to have standards to become vocational teachers. The experience of novice teachers is constructed to provide several information and input to vocational education providers. Qualitative research with a descriptive analysis approach was carried out. A total of 11 vocational teachers who are beginners in their careers (1-3 years of teaching) were selected to be participants. Open coding and axial coding were used in data analysis. The findings in the study that teachers' experiences are identified in four aspects, namely understanding, activities, problems, and the use of technology in their work. The important finding is that increasing the age of work experience increases social and professional competence and the age of beginner vocational teachers to have better technology closeness.
\end{abstract}

Keywords - Beginner teacher, vocational teacher, professional teacher

DOI: $10.18421 /$ TEM102-28

https://doi.org/10.18421/TEM102-28

Corresponding author: Nur Kholifah,

Yogyakarta State University - Kampus Karang Malang, Jl. Colombo No.1, Karang Gayam, Caturtunggal, Kec. Depok, Kabupaten Sleman, Daerah Istimewa Yogyakarta-

Indonesia.

Email: nur.kholifah@uny.ac.id

Received: 01 January 2021.

Revised: 22 April 2021.

Accepted: 27 April 2021.

Published: 27 May 2021.

(cc) BY-NC-ND]C 2021 Nur Kholifah at al; published by UIKTEN. This work is licensed under the Creative Commons Attribution-NonCommercial-NoDerivs 4.0 License.

The article is published with Open Access at www.temjournal.com

\section{Introduction}

Vocational education in Indonesia has been established as a solution in overcoming youth unemployment [1]. Recognizing the importance of the mandatory role of the Indonesian government, the providers of vocational education have to have a comprehensive strategy, especially in dealing with uncertain future changes. Functionally, vocational education creates graduates in three domains, namely work, continuing a higher level and entrepreneurship. However, BPS data has released that vocational education graduates are at the highest level in contributing to the unemployment rate of $8.49 \%$ in February 2020 [2]. Some discussions about the data, are not strong enough if only interpreted fundamentally, but there is a need to look deeper, such as the number of vocational administrators, the acceptance of vocational teachers and their career development, demographic location, and others [3]. However, this study focuses on human resource preparation namely teaching staffs that have to have academic qualifications. This is in line with the role of vocational teachers as the key in parsing the high unemployment rate among vocational graduates.

Vocational teachers are teachers who have special skills in their fields [4]. The intended expertise is in addition to methodological skills, also practical skills, namely experience in projects in industry as well as experience in various trainings according to fields [5]. However, teachers are considered as a central and vital role in the quality of education [6], [7]. The fundamental reason is teaching activities that directly touch and influence or change old understanding into new understanding in students. Meanwhile, vocational teachers construct their experiences from the transfer of knowledge and skills acquired during undergraduate education [8]. Of course, this condition is not enough to provide experience to students as their working capital. During undergraduate education, novice teachers take part in the PPLK program and industrial apprenticeships. However, the adequacy of 
experience is limited. Thus, vocational education providers need to have clear standards.

Teacher de-professionalization [9], [10], is frequent and becomes a major problem. These problems include recruitment standards to become vocational teachers who do not have certain criteria, general and uncontrolled competency of vocational teachers, vocational teacher training education who are still looking for formulation, and the development of continuous teacher education [11]. Vocational education as a complete system, where vocational teachers act as trainers, educators, and tell the conditions in which students will work according to their fields. The next question will arise, what if the acceptance of vocational teachers does not have the quality it should be? This question is the focus of researchers to discuss. Through a novice teacher, the answers to these questions will be constructed. Recommendations from various findings, how their experiences in constructing learning are described in this study. Specifically, it is important that providers of vocational education have standards in the acceptance of vocational teachers or provide solutions to make novice teachers reach the preprofessional age.

\section{Research Methods}

This study was designed to explore the experiences of (expressing feelings) novice teachers in vocational schools. This study adopts a qualitative research methodology as an exploratory tool in collecting data and giving meaning to the data. Phenomenology that is born from the experience of vocational teachers is important in explaining the mode of understanding [12]. This study describes that phenomenology makes an interest in understanding social phenomena from the point of view of the actor and describes the world as experienced by participants or subjects.

\subsection{Participants}

Participants in this study were 11 vocational teachers including $(\mathrm{N}=9)$ male who are 23-24 years of age and $(\mathrm{N}=2)$ female with 24 years of age. The participants were identified as beginner level vocational teachers in the Yogyakarta, Banten and Lampung-Indonesia regions. Although the participants came from different regions, the characteristics of the teaching experience were the focus of discussion in this study. Based on their experience, they were categorized into five experience ages, (1) less than 1 year old $(\mathrm{N}=3) ;(2)$ 1 year old $(\mathrm{N}=2)$; (3) aged 1 -2 years $(\mathrm{N}=2)$; (4) 2 years old $(\mathrm{N}=3)$; and (5) 3 years old $(\mathrm{N}=1)$. In addition, participants are drawn from two educational providers, namely public schools, and general schools (institutions or foundations). The foundations involved are YPWKS at Cilegon and Tunas Bangsa Wanareja, the rest of the participants are involved in public schools. Table 1 shows the detailed descriptions of participants, and they have been restricted to protect their identities.

Table 1. Participants' Demographics

\begin{tabular}{|c|c|c|c|}
\hline Participant(s) & Age & $\begin{array}{c}\text { Teaching } \\
\text { Experience }\end{array}$ & Gander \\
\hline Participant 1 & $\begin{array}{c}24 \\
\text { Years }\end{array}$ & 1 Year & Male \\
\hline Participant 2 & $\begin{array}{c}24 \\
\text { Years }\end{array}$ & 2 Years & Male \\
\hline Participant 3 & $\begin{array}{c}24 \\
\text { Years }\end{array}$ & $\begin{array}{c}\text { Less than } 1 \\
\text { Year }\end{array}$ & Male \\
\hline Participant 4 & $\begin{array}{c}24 \\
\text { Years }\end{array}$ & $\begin{array}{c}\text { Less than } 1 \\
\text { Year }\end{array}$ & Female \\
\hline Participant 5 & $\begin{array}{c}24 \\
\text { Years }\end{array}$ & 2 Years & Male \\
\hline Participant 6 & $\begin{array}{c}24 \\
\text { Years }\end{array}$ & $\begin{array}{c}\text { More than } 1 \\
\text { Year }\end{array}$ & Female \\
\hline Participant 7 & $\begin{array}{c}23 \\
\text { Years }\end{array}$ & $\begin{array}{l}\text { More than } 1 \\
\text { Year }\end{array}$ & Male \\
\hline Participant 8 & $\begin{array}{c}23 \\
\text { Years }\end{array}$ & $\begin{array}{c}\text { Less than } 1 \\
\text { Year }\end{array}$ & Male \\
\hline Participant 9 & $\begin{array}{c}24 \\
\text { Years }\end{array}$ & 2 Years & Male \\
\hline Participant 10 & $\begin{array}{c}23 \\
\text { Years }\end{array}$ & 1 Year & Male \\
\hline Participant 11 & $\begin{array}{c}23 \\
\text { Years }\end{array}$ & 3 Years & Male \\
\hline
\end{tabular}

\subsection{Interview Procedure}

The research process was complemented by a snowball sampling strategy [13]. The participants were ensured according to the inclusion criteria. Data collection in the form of interviews was collected in 2020. Interviews were conducted with the aim of understanding their world of work from the subject's point of view, revealing meaning based on experiences that have been carried out, and revealing their lives before scientific explanation [12], [14]. The specific purpose is to describe the experience, the construction of the experience, and the problems that appear. The interview stopped at saturation level, data collection and analysis continued to the point where no new codes or concepts emerged [15], [16].

Examples of questions asked by participants include: (a) Describe your opinion about the vocational teaching profession? (b) How would you describe the true experience of being a vocal teacher; (c) What difficulties did you have while teaching theory or practice? (d) What are the difficulties of becoming a vocational teacher? and others. Interviews were recorded using digital audio and detailed notes. The recordings were transcribed word 
by word and the transcribe results were submitted to the participants for data accuracy. All data in the report is anonymous to protect their identity. The data is then coded and used as a theme [10]. Data credibility was reviewed from two researchers as data reviewers for questions and themes. This process is used as data verification or inter-rater reliability [17].

\subsection{Data Analysis}

Data analysis was done by means of open and axial code. Open coding is the labelling and categorization of phenomena. While axial coding is intended to create a theme. Both are done from patterns, themes that emerge from the results of the conversation, vocabulary, and activities are adopted.

\section{Result and Discussion}

The narrative in this study provides important information about the experience of being a vocational teacher with limited experience. Researchers find closed (limited) space in explaining questions. This situation is a natural phenomenon when viewed from the age in teaching work. However, some of the participants made strong and deep arguments.

\subsection{Vocational Teacher Understanding: Beginner Teacher Perspective}

Teachers' understanding of vocational is a requirement that every teacher needs to understand, especially before they make decisions as a teacher. This is not just a simple decision, but the extent to which they are able to describe themselves and their long-term plans. In their simple thinking that vocational teachers oversee is a delivering material that measures three aspects. However, in practice being a vocational teacher is not that simple [18]. Challenges and participation in skills development are criteria that have to be followed.

In my opinion, vocational teachers are a very calculated profession, especially in / vocational schools /, vocational teachers are very dominant in providing learning to students both knowledge and skills, so that the quality of students is in the hands of vocational teachers / ... \% [P2.M].

.... / teach vocational sciences in accordance with the vocational curriculum structure, improve knowledge competence and skills in certain fields of science, as well as apply and cultivate the character of students to welcome the business world and the industrial world. [P7.M]
However, the participant's statement seems simple with a limited meaning. Researchers realized that the pile of work occurred at senior level vocational teachers.

\subsection{Teacher Activities: Beginner Teacher Perspectives}

Most of the novice teachers understand that teachers' activities are limited to the administration of learning and teaching [19], as is the description of pedagogical competencies. Beginner teachers with 2 years of teaching experience or more have increased activity. Researchers concluded that teacher activity is directly proportional to the length of teaching. As is the case, participant 4 (teaching age is less than 1 year),

The activities I do /... / carry out the theoretical and practical learning process, manage the workshop, plan learning activities, carry out learning activities, assess learning outcomes, guide, and train students, carry out additional assignments. [P4.F].

They begin to adapt to the new environment with their new status, namely the novice vocational teacher. More increasing was done in participants 9 and 11 with experience age of 2 and 3 years.

... / making go-cars, running a special motorcycle production unit because of the MOU with HONDA, repairing existing machines / tools at school with students being guided by me to gain work experience, making SST tools. [P9.M].

... / planning the accreditation process, creating a certified workshop management system, having a TUK (competency test site) unit for the LSP BNSP, in collaboration with the IDUKA to make a curriculum design. [P11.M]

Researchers analyzed that the elements of competence were carried out gradually according to the age of vocational teachers entering the world of work. Initially they emphasized pedagogic competence, as technical competence ages and relations outside the vocational school habituation.

\subsection{Arise of Problems}

While carrying out their duties as a novice vocational teacher, they have experienced some difficulties. Adaptation to work and problems in work, especially education, are common things. This is part of maturing themselves in their work. Not far from the activities carried out, generally vocational teachers have constructed several problems in mastery of 
material, adjustment in curriculum development, and limited infrastructure. More than that, vocational teachers are required to have a strategy in overcoming these problems. Participants have specifically stated the problems.

.... / difficulties when teaching the theory of teaching materials that are incomplete according to the curriculum, and children are always confused about what to explain because of the lack of learning media. To teach practice between. [P6.F]

.... / At the time of learning theory, limited infrastructure such as information and textbooks made it difficult to dynamize the learning process (SCL). In practicum learning, the difficulty lies in the limitations of practical tools and supplies of consumables. [P1.M]

In general, the problem expressed by the participants was mastery of the material. Learning that comes from undergraduate education or the recognition of past experiences is not sufficient and even experiences are not complete. Fejes \& Kopsen [4], reinforces that to become a vocational teacher, one has to have self-identities such as pedagogic abilities, training communities and work communities, which is the way vocational teachers become professionals.

\subsection{The Role of Technology in Learning}

In the last theme, the researchers describe their work in facing the 4.0 era learning and innovations that have been carried out. It is important for vocational teachers that learning involves the role of technology.
.... / displays an audio-visual form using in focus, introduces the latest technology, how to repair, troubleshooting, vehicle work systems that are on social media (YouTube), not only that, sometimes I make videos then I upload them to YouTube so students can observe them well, then when There are questions that students explain in front of the camera and then upload them on their personal social media. [P3.M]

... / Create virtual games about materials, make animated videos, take advantage of educational platforms (during the pandemic). [P5.M]

Teachers use the role of technology as a source of information in the learning process [20]. More than that, making it a medium in learning. Thus, Vocational teachers, even at the age of experience work at a beginner level. However, the closeness of technology is very fast to master.

\section{Conclusion}

The qualitative research from the experience of novice vocational teachers is concluded in four aspects, namely understanding, activities, problems and the role of technology with the following findings: (1) simple understanding has been explained by novice vocational teachers with their tasks constructed from pedagogical competencies while other competencies have not been constructed; (2) activity increases with age of teaching experience, namely from teaching to shift to other elements such as self-development and social relations; (3) problems occur in the range of their teaching activities, limited material and limited facilities, then vocational teachers are required to be creative; and (4) in mastery of technology, vocational teachers at the beginning of their career have good mastery and practice, especially in learning resources and developing technology-based learning media. Vocational education providers need to consider the instruments in the acceptance of vocational teachers for their mastery of the material and their career development. 


\section{References}

[1]. Yunikawati, N. A., Prayitno, P. H., Purboyo, M. P., Istiqomah, N. M., \& Puspasari, E. Y. (2018). Causes and Solution to Reduce Unemployment Vocational School Graduate in Indonesia. UNEJ e-Proceeding, 200-206.

[2]. Badan Pusat Statistik. (2020). Februari 2020: Tingkat Pengangguran Terbuka (TPT) Sebesar 4,99 Persen. Jakarta: Badan Pusat Statistik.

[3]. Keijzer, R., Admiraal, W., Van der Rijst, R., \& Van Schooten, E. (2020). Vocational identity of at-risk emerging adults and its relationship with individual characteristics. International Journal for Educational and Vocational Guidance, 20(2), 375-410. https://doi.org/10.1007/s10775-019-09409-z

[4]. Fejes, A., \& Köpsén, S. (2014). Vocational teachers' identity formation through boundary crossing. Journal of Education and Work, 27(3), 265-283. https://doi.org/10.1080/13639080.2012.742181

[5]. Nurtanto, M., Arifin, Z., Sofyan, H., Warju, W., \& Nurhaji, S. (2020). Development of model for professional competency assessment (Pca) in vocational education: Study of the engine tune-up injection system assessment scheme. Journal of Technical Education and Training, 12(2), 34-45.

[6]. Goodwin, A. L., \& Kosnik, C. (2013). Quality teacher educators $=$ quality teachers? Conceptualizing essential domains of knowledge for those who teach teachers. Teacher Development, 17(3), 334-346. https://doi.org/10.1080/13664530.2013.813766

[7]. Idris, F., Hassan, Z., Ya'acob, A., Gill, S. K., \& Awal, N. A. M. (2012). The role of education in shaping youth's national identity. Procedia-Social and Behavioral Sciences, 59, 443-450. https://doi.org/10.1016/j.sbspro.2012.09.299

[8]. Schaap, H., Baartman, L., \& De Bruijn, E. (2012). Students' learning processes during school-based learning and workplace learning in vocational education: a review. Vocations and learning, 5(2), 99117. https://doi.org/10.1007/s12186-011-9069-2

[9]. Milner IV, H. R. (2013). Policy Reforms and DeProfessionalization of Teaching. National Education Policy Center.

[10]. McDaniel, T. R. (1979, January). The deprofessionalization of teachers. In The Educational Forum (Vol. 43, No. 2, pp. 229-238). Taylor \& Francis Group.

https://doi.org/10.1080/00131727909338328
[11]. Grollmann, P. (2008). The quality of vocational teachers: Teacher education, institutional roles and professional reality. European Educational Research Journal, 7(4), 535-547. https://doi.org/10.2304/eerj.2008.7.4.535

[12]. Kvale, S., \& Brinkmann, S. (2009). Interviews: Learning the craft of qualitative research interviewing. Sage.

[13]. Marshall, C., \& Rossman, G. B. (2014). Designing qualitative research. Sage publications.

[14]. Sher-Censor, E., Benish-Weisman, M., Gal, L., \& Karni, S. (2018). The associations between national identity and adjustment: What can we learn from autobiographical narratives?. International Journal of Intercultural Relations, 67, 12-24. https://doi.org/10.1016/j.ijintrel.2018.08.003

[15]. Bryman, A. (2016). Social research methods. Oxford University Press.

[16]. van Rijnsoever, F. J. (2017). (I can't get no) saturation: a simulation and guidelines for sample sizes in qualitative research. PloS one, 12(7), e0181689.

https://doi.org/10.1371/journal.pone.0181689

[17]. Constas, M. A. (1992). Qualitative analysis as a public event: The documentation of category development procedures. American Educational Research Journal, 29(2), 253-266. https://doi.org/10.2307/1163368

[18]. Bakar, R. (2018). The influence of professional teachers on Padang vocational school students' achievement. Kasetsart Journal of Social Sciences, 39(1), 67-72. https://doi.org/10.1016/j.kjss.2017.12.017

[19]. Harold W. Kohl, I. I. I., Cook, H. D., Environment, C. on P. A. and P. E. in the S., Board, F. and N., \& Medicine, I. of. (2013). Approaches to Physical Education in Schools. In Educating the Student Body: Taking Physical Activity and Physical Education to School. Washington (DC): National Academies Press (US).

[20]. Mahini, F., Forushan, Z. J. A., \& Haghani, F. (2012). The importance of teacher's role in technology-based education. Procedia-Social and Behavioral Sciences, 46, 1614-1618. https://doi.org/10.1016/j.sbspro.2012.05.348 